\author{
Jan Gałka* \\ ORCID: 0000-0003-0485-6060
}

Uniwersytet SWPS Filia we Wrocławiu

https://doi.org/10.19195/1733-5779.30.10

\title{
Nieskazitelność charakteru w kontekście zatarcia skazania
}

JEL Classification: K10, K14, K19

Słowa kluczowe: nieskazitelność charakteru, zatarcie skazania, prawo administracyjne, prawo karne law

Keywords: impeccable character, expungement of criminal record, administrative law, criminal

Abstrakt: W niniejszym artykule autor rozważa, czy jest możliwe, mając na uwadze postanowienia artykułu 106 k.k., wykazywanie, że dana osoba nie ma nieskazitelnego charakteru, poprzez powoływanie się właściwego organu na zatarte skazanie. Jak stanowi powołany przepis, z chwilą zatarcia skazania uważa się je za niebyłe. Oznacza to, iż organy władzy publicznej nie mogą wywodzić żadnych skutków prawnych z faktu, że dana osoba została w przeszłości skazana, jeżeli to skazanie uległo już zatarciu. Oczywiście prawo nie może wymazać faktu, iż ktoś dopuścił się w przeszłości czynu nagannego i nielegalnego. Mając to na uwadze, powstaje pytanie, w jaki sposób wykazać, że dana osoba nie cechuje się nieskazitelnym charakterem, ponieważ dopuściła się w przeszłości czynu nagannego i nielegalnego, bez powoływania się na prawomocne skazanie, które uległo już zatarciu.

\section{Impeccable character in the context of the expungement of criminal record}

Abstract: In this article, the author considers the problem of whether it is possible, with regard to the resolution of Article 106 of the Polish Penal Code, to prove that someone is not a person of impeccable character by using an expunged criminal record as evidence. As this article claims, from the moment of its expungement, the conviction is considered non-existent. It means that the organs of public authority cannot draw any legal consequences from the fact that someone had been convicted in the past if the sentence is already expunged. But the law cannot obliterate the fact that

* Opiekun naukowy (Scientific Tutor) — dr Mateusz Radajewski 
someone had done, in the past, something reprehensible. The question is how to prove that someone is not a person of impeccable character because he or she had done something reprehensible and illegal, without pointing out that this person was validly sentenced in the past, if their criminal record has already been expunged.

\section{Wstęp}

Charakterystyczną cechą zawodów zaufania publicznego jest powiązanie kompetencji wymaganych do ich wykonywania z kwalifikacjami osobistymi osoby, która taki zawód zamierza wykonywać lub wykonuje. Ma to szczególne znaczenie ze względu na przedmiot podejmowanych czynności zawodowych. Dotyczy on sfery osobistej, majątkowej, prywatnej, często wręcz intymnej, adresata usługi. Wynika z tego, że osoba wykonująca zawód zaufania publicznego musi odznaczać się szczególnymi kompetencjami, nie tylko zawodowymi, lecz również kompetencjami miękkimi lub takimi cechami charakteru. Musi być to osoba fachowa, empatyczna, honorowa, samodzielna, odpowiedzialna. Są to cechy, które ze swej istoty nie są stwierdzane w postaci zaświadczeń, certyfikatów, dyplomów itp. Możliwość ich dokładnego określenia jest niemożliwa w zwykłym toku czynności postępowania wyjaśniającego prowadzonego w sprawie. Nie sposób zbadać w krótkim okresie (miesiąca, ewentualnie dwóch), w jaki sposób kandydat do wykonywania zawodu regulowanego zachowuje się, gdy nie jest objęty procesem kwalifikacyjnym, jaki jest jego stosunek do aspirowanego zawodu, do innych ludzi, jak się zachowa w sytuacjach stresujących czy niejednoznacznych. Często tak nieuchwytnych cech, faktów nie da się stwierdzić, nawet pozostając we wspólnym pożyciu. Organ administracji publicznej jest skazany na wnioskowanie o kompetencjach miękkich jedynie na podstawie całokształtu dowodów przeprowadzanych w sprawie (art. 80 k.p.a.). Głównie będą to różnego typu dokumenty w rozumieniu: „treść oświadczenia woli lub wiedzy, utrwalona na piśmie lub w formie dokumentu elektronicznego, opatrzona podpisem osoby sporządzającej dokument"1, a w szczególności dokumenty urzędowe, korzystające z domniemań prawdziwości i zgodności z prawdą tego, co zostało w nich urzędowo zaświadczone ${ }^{2}$. Mogą to być również źródła osobowe w postaci zeznań świadków.

Wymóg określenia u kandydata cech psychologicznych wynika z przepisów prawa. Przykładami takich przepisów są art. 65 ustawy z dnia 26 maja 1982 roku Prawo o adwokaturze ${ }^{3}$ i art. 24 ust. 1 ustawy z dnia 6 lipca 1982 roku o radcach prawnych $^{4}$ które stanowią, że na listę adwokatów albo radców prawnych może

1 P.M. Przybysz, [w:] Kodeks postępowania administracyjnego. Komentarz, Warszawa 2017, komentarz do art. 76, teza 1.

2 A. Wróbel, [w:] Kodeks postępowania administracyjnego. Komentarz, red. A. Wróbel, M. Jaśkowska, M. Wildbrandt-Gotowicz, Warszawa 2018, komentarz do art. 76, teza 7.

3 Dz.U. z 2017 r. poz. 2368 z późn. zm.

4 Dz.U. z 2017 r. poz. 1870 z późn. zm. 
być wpisany ten, kto jest nieskazitelnego charakteru i swym dotychczasowym zachowaniem daje rękojmię prawidłowego wykonywania zawodu adwokata albo radcy prawnego. Reszta $\mathrm{z}$ wymienionych $\mathrm{w}$ tych artykułach przesłanek dotyczy już stanów rzeczy stwierdzalnych, bez potrzeby odwoływania się do swobodnego uznania organu administracji publicznej. Problem wynikający z określenia, czy kandydat do wpisu na listę cechuje się nieskazitelnym charakterem, najczęściej jest rozwiązywany poprzez sprawdzenie, czy kandydat ten był albo jest skazany prawomocnym wyrokiem za popełnione przestępstwo, nie wyłączając wyroku warunkowo umarzającego postępowanie jako wyroku stwierdzającego winę ${ }^{5}$. Chociaż, co słusznie się kontestuje, nie można uznać za uprawnione twierdzenie, że popełnienie czynu zabronionego jako przestępstwa, w odległej przeszłości, często wiele lat po zatarciu skazania, jakoby niwelowało możliwość zostania uznanym za osobę nieskazitelnego charakteru, gdyż taka interpretacja narusza bez wątpienia art. 65 ust. 1 Konstytucji $\mathrm{RP}^{6}$, jak również dyspozycję art. 31 ust. 3 Konstytucji RP, będąc rażącym naruszeniem zasady proporcjonalności.

\section{Zatarcie skazania}

$\mathrm{Z}$ chwilą zatarcia skazania uważa się je za niebyłe, a wpis o nim usuwa się z rejestru skazanych (art. 106 k.k.). Zatarcie skazania nie jest domniemaniem, nie można w związku z tym przeprowadzić przeciwko niemu przeciwdowodu. Jest fikcją prawną, że skazanie nigdy nie nastąpiło ${ }^{7}$ albo wręcz nie popełniono przestępstwa, którego to skazanie dotyczy ${ }^{8}$. Powszechne jest mniemanie o celu tej instytucji, polegającym na umożliwieniu skazanemu rozpoczęcia nowego życia, bez piętna skazania utrudniającego, a w niektórych przypadkach wręcz uniemożliwiającego, normalne funkcjonowanie $\mathrm{w}$ społeczeństwie, podjęcie pracy, sprawowanie funkcji publicznych. Zatarcie skazania ma aspekt humanitarny. Jest ono zbieżne z uznaniem przyrodzonej i niezbywalnej godności człowieka, która jest źródłem wolności i praw człowieka i obywatela (art. 30 Konstytucji RP). Warto wskazać, że napiętnowanie osoby uprzednio skazanej, jako że pociąga za sobą brzemienne skutki, jest ograniczeniem konstytucyjnych praw i wolności, a takie ograniczenia mogą być ustanawiane tylko wtedy, gdy są konieczne w demokratycznym państwie, dla ochrony innych ważnych wartości (art. 31 ust. 3 Konstytucji RP). Podstawowym

5 „Nie można zatem powiedzieć, że osoba, która popełniła przestępstwo, jest nieskazitelna, nawet jeżeli wcześniej i później jej życiowa postawa i zachowanie nie budziły jakichkolwiek zastrzeżeń" — wyrok NSA z 2 sierpnia 2016 roku, II GSK259/15, LEX nr 2142251.

6 Wyrok NSA w Warszawie z 17 listopada 2017 roku, II GSK 447/16, LEX nr 2430732; w podobnym kierunku zmierza argumentacja w wyroku NSA w Warszawie z 14 kwietnia 2016 roku, II GSK 2647/14, LEX nr 2139464.

7 A. Marek, [w:] Kodeks karny. Komentarz, Warszawa 2010, komentarz do art. 106, teza 4.

${ }^{8}$ I. Zgoliński, [w:] Kodeks karny. Komentarz, red. V. Konarska-Wrzosek, Warszawa 2016, komentarz do art. 106, teza 1; teza wyroku SN z 29 sierpnia 2013 roku, IV KK 168/13, LEX nr 1403563. 
prawem, które narusza rejestracja skazania, jest prawo do równego traktowania, uznane za jedno z podstawowych praw człowieka zarówno przez polską konstytucję (art. 32 Konstytucji RP), jak i akty prawa międzynarodowego ${ }^{9}$. Przynajmniej ze względu na zasadę proporcjonalności wyrażoną w art. 31 ust. 3 Konstytucji RP, postanowienia art. 106a k.k. mogą budzić wątpliwości ich konstytucyjności, z powodu całkowitego wyłączenia możliwości zatarcia skazania. Oczywiście dopuszczenie się przestępstwa przeciwko wolności seksualnej i obyczajności na szkodę małoletniego poniżej 15 roku życia jest okropnym występkiem lub nawet zbrodnią, jednak wprowadzenie aż tak rygorystycznego prawa i dodatkowo zawężenie jego zakresu jedynie do tego rodzaju czynów jest wysoce dyskusyjne.

Trzeba zauważyć, że zatarcie skazania nie wynika jedynie z art. 107 k.k. dotyczącego upływu określonego czasu od wykonania, darowania albo przedawnienia wykonania kary, środka karnego, środka kompensacyjnego, przepadku albo wykonania środka zabezpieczającego. Podstawą zatarcia może być również:

— depenalizacja czynu (art. $4 \S 4$ k.k.) — czyn objęty wyrokiem nie jest według nowej ustawy zabroniony pod groźbą kary;

- upływ 6 miesięcy od zakończenia okresu próby, przy warunkowym zawieszeniu wykonania kary (art. $76 \S 1$ k.k.). Jeżeli wobec skazanego orzeczono grzywnę, środek karny, przepadek lub środek kompensacyjny, to zatarcie skazania nie może nastąpić przed ich wykonaniem, darowaniem albo przedawnieniem ich wykonania. Zatarcie skazania nie może nastąpić przed wykonaniem środka zabezpieczającego (art. $76 \S 2$ k.k.);

— akt łaski Prezydenta RP (art. 139 Konstytucji RP) ${ }^{10}$.

Skutkiem zatarcia skazania jest możliwość pomijania przez byłego skazanego tego faktu przy składaniu wszelkiego rodzaju deklaracji, w tym o charakterze urzędowym. Pominięcie faktu skazania przy składaniu zeznań albo stwierdzenie, iż jest się niekaranym, nie wypełnia znamion przestępstwa $\mathrm{z}$ art. $233 \S 1$ k.k. ${ }^{11}$ Najważniejszym następstwem zatarcia skazania, z uwagi na art. 7 Konstytucji RP stanowiący, iż organy władzy publicznej działają na podstawie i w granicach prawa, jest to, że nie mogą one wywodzić z zatartego skazania jakichkolwiek skutków prawnych wobec osoby, której to zatarcie dotyczy. Samo skazanie nie może w tym wypadku stanowić podstawy do różnicowania traktowania podobnych podmiotów, wykluczone jest w związku z tym ograniczanie praw i wolności byłego skazanego tylko z powodu jego skazania, gdyż organy władzy publicznej związane są dyspozycją normy wynikającej z art. 106 k.k., jednoznacznie nakazującej traktowanie skazania jako niebyłego, jak gdyby nigdy nie zaistniało. Natomiast pogląd, na któ-

${ }^{9}$ M.in. art. 14 EKPC, art. 21 Karty praw podstawowych UE, art. 25 MPPOiP.

10 N. Kłączyńska, [w:] Kodeks karny. Część ogólna. Komentarz, red. J. Giezek, Warszawa 2012, komentarz do art. 106, teza 2.

11 G. Bogdan, [w:] Kodeks karny. Część ogólna, t. 1, cz. 2. Komentarz do art. 53-116, red. W. Wróbel, A. Zoll, Warszawa 2016, komentarz do art. 106, teza 2. 
ry już wcześniej zwrócono uwagę, iż fikcja prawna wynikająca z zatarcia skazania dotyczy również samego faktu popełnienia przestępstwa, wynika z rozumowania z konsekwencji ${ }^{12}$. Jeżeli przyjmuje się fikcję prawną, że skazanie nie nastąpiło, to trzeba uznać, że popełnienie przestępstwa będące podstawą skazania również nie nastąpiło, w innym wypadku implikowałoby to irracjonalny wniosek, iż z chwilą zatarcia skazania przestępstwo będące podstawą wyroku mogłoby być podstawą wydania nowego orzeczenia. Zasada ne bis in idem wyrażona w art. 17 pkt 7 k.p.k. dotyczy jedynie postępowania karnego prawomocnie zakończonego, a takim prawomocnym zakończeniem jest między innymi wyrok skazujący. Uznając to skazanie za niebyłe, przy nierozciągnięciu zakresu fikcji prawnej wynikającej z zatarcia skazania na popełnienie samego przestępstwa, odpadłaby przesłanka obligatoryjnego niewszczynania lub umorzenia postępowania karnego, co pociągałoby za sobą obligatoryjne wszczęcie po raz kolejny postępowania karnego ze względu na zasadę działania organów ścigania ex officio (art. 10 k.p.k.).

\section{Wpis na listę jako decyzja administracyjna}

Wpis na listę czy to adwokatów, czy radców prawnych jest decyzją administracyjną, czyli przejawem woli organu administracji publicznej władczo narzucającego swoje stanowisko poprzez rozstrzygnięcie konkretnej sprawy konkretnej osoby fizycznej, na podstawie powszechnie obowiązujących przepisów prawa administracyjnego, w postępowaniu unormowanym przez przepisy proceduralne ${ }^{13}$. W obu wypadkach jest ona podejmowana w formie uchwały ciała kolegialnego, którym jest odpowiednio okręgowa rada adwokacka i rada okręgowej izby radców prawnych. Wymaganiami stawianymi wobec kandydata ubiegającego się o wpis na listę adwokatów albo radców prawnych są: nieskazitelny charakter i dawanie swym dotychczasowym zachowaniem rękojmi prawidłowego wykonywania zawodu adwokata albo radcy prawnego; korzystanie w pełni z praw publicznych oraz pełna zdolność do czynności prawnych; ukończenie wyższych studiów prawniczych w Rzeczypospolitej Polskiej i uzyskanie tytułu magistra lub zagranicznych studiów prawniczych uznanych w Rzeczypospolitej Polskiej; odbycie w Rzeczypospolitej Polskiej aplikacji adwokackiej i złożenie egzaminu adwokackiego, z zastrzeżeniem art. 66 ust. 1 i 2, albo aplikacji radcowskiej i złożenie egzaminu radcowskiego, z zastrzeżeniem art. 25 ust 1 i 2 (art. 65 ustawy Prawo o adwokaturze i art. 24 ust. 1 ustawy o radcach prawnych). Co odnosi się zarówno do adwokatów, jak i radców prawnych, odpowiednio okręgowa rada adwokacka i okręgowa rada izby radców prawnych mogą odmówić wpisu na listę jedynie przy niespełnieniu warunków wpisu na tę listę. Oba podmioty mają prawo wglądu do akt osobowych i dyscypli-

12 Zob. wyrok SN z 18 czerwca 2009 roku, IV KK 164/09, LEX nr 512114, wydaje się iść podobnym tokiem rozumowania.

13 Uchwała SN z 5 lutego 1988 roku, III AZP 1/88, LEX nr 11678. 
narnych osoby ubiegającej się o wpis (art. 64 ust. 4 ustawy Prawo o adwokaturze i art. 24 ust. 2c ustawy o radcach prawnych). Zarówno okręgowa rada adwokacka, jak i okręgowa rada izby radców prawnych są innymi podmiotami powołanymi $\mathrm{z}$ mocy prawa do załatwiania spraw indywidualnych $\mathrm{w}$ drodze decyzji administracyjnej (art. 1 pkt 2 w zw. z pkt 1 k.p.a.) i są w rozumieniu k.p.a. uważne za organy administracji publicznej (art. $5 \S 2$ pkt 3). Do postępowania dotyczącego wpisu na listę będą miały zastosowanie przepisy k.p.a.

Organy administracji publicznej działają na podstawie przepisów prawa (art. 6 k.p.a.). Zasada praworządności wyrażona w k.p.a. pokrywa się z przytoczoną już zasadą wyrażoną $\mathrm{w}$ art. 7 Konstytucji RP. Pomimo nieużycia określenia „i w granicach” nie może budzić wątpliwości, iż jeżeli organy mają działać jedynie na podstawie prawa, to zawiera się $\mathrm{w}$ tym dyspozycja działania również $\mathrm{w}$ ramach wyznaczonych przez to prawo. Mając na uwadze, iż przywołane podmioty mogą odmówić wpisu na listę tylko wtedy, gdy kandydat nie spełnia warunków wymaganych do wpisu, a contrario można stwierdzić, że podmioty te nie mogą odmówić wpisu na listę z jakichkolwiek innych powodów. Większość ze wskazanych przesłanek jest możliwa do stwierdzenia jedynie na podstawie dowodu $\mathrm{z}$ dokumentu. Jednakże warunek dawania rękojmi prawidłowego wykonywania zawodu adwokata albo radcy prawnego, a tym bardziej nieskazitelny charakter już tak proste do stwierdzenia nie jest. Obie ustawy przewidują wymóg dołączenia do wniosku o wpis informacji o niekaralności z Krajowego Rejestru Karnego opatrzoną datą nie wcześniejszą niż miesiąc przed złożeniem wniosku (art. 68 ust. 3 pkt 1 ustawy Prawo o adwokaturze i art. 24 ust. 2a pkt 1 ustawy o radcach prawnych). Jest to jedno ze źródeł dowodowych pozwalających ustalić tylko pośrednio, czy kandydat spełnia rozważany warunek. Sam wymóg niekaralności expressis verbis nie został uznany za podstawę do odmowy wpisu na listę, co jednoznacznie prowadzi do konstatacji, że w uzasadnieniu uchwały odmawiającej wpisu na listę na ten fakt, jako na samoistną podstawę odmowy, powołać się nie można ${ }^{14}$.

\section{Możliwość traktowania zatartego skazania jako podstawy odmowy wpisu}

Mając na względzie samą istotę zatarcia skazania, można uznać, że zatarte skazanie nie może być podstawą oparcia na nim uzasadnienia odmowy wpisu na listę ze względu na niespełnienie warunku nieskazitelnego charakteru lub dawania rękojmi prawidłowego wykonywania zawodu. Co więcej, na co zwrócono wcześniej uwagę, sam fakt skazania nie może dawać samoistnej podstawy do odmowy takiego wpisu, gdyż nie został on uznany przez ustawodawcę za przesłankę negatywną wpisu na listę, a podstawą odmowy wpisu na listę może być jedynie niespełnienie warunków wymaganych do tego wpisu. Z faktu skazania prawomocnym wyro-

14 Wyrok NSA w Warszawie z 7 marca 2013 roku II GSK 1825/12, LEX nr 1305501. 
kiem sądu, bo tylko taki może prowadzić do obalenia domniemania niewinności (art. $5 \S 1$ k.p.k.), można wyciągać pośrednie wnioski co do cech charakteru lub istnienia podstaw do zawierzenia, iż kandydat daje rękojmię prawidłowego wykonywania zawodu. Spełnienie ostatniej z wymienionych przesłanek ocenia się ze względu na „dotychczasowe zachowanie”. Oznacza, że ocenie podlega cały dotychczasowy (do złożenia wniosku o wpis) okres życia kandydata na adwokata lub radcę prawnego, a obowiązkiem organu administracji publicznej ,jest branie pod uwagę i ocenianie wszelkich dostępnych danych dotyczących osoby ubiegającej się o wpis na listę adwokatów, a nie tylko jednej okoliczności"15, co wynika z zasady prawdy obiektywnej wyrażonej w art. 7 k.p.a. i dyrektyw wypływających $\mathrm{z}$ art. $77 \S 1$ i art. 80 k.p.a.

O nieskazitelności charakteru świadczą takie przymioty osobiste, jak: uczciwość w życiu prywatnym i zawodowym, uczynność, pracowitość, poczucie odpowiedzialności za własne słowa i czyny, stanowczość, odwaga cywilna, samokrytycyzm, umiejętność zgodnego współżycia z otoczeniem. Pojęcie rękojmi jest zdefiniowane w słownikach języka polskiego jako ,uroczyste poręczenie, zagwarantowanie, zapewnienie czegoś”. Szereg przepisów p.o.a. bez wyraźnego posługiwania się pojęciem rękojmi, zalicza do niego inne jeszcze wymogi w tym np. kwalifikacje zawodowe ${ }^{16}$.

Stwierdzenie posiadania lub nieposiadania tych przymiotów przez kandydata do wpisu na listę podlega normalnemu postępowaniu dowodowemu uregulowanemu w k.p.a., który w art. $75 \S 1$ nakazuje dopuścić jako dowód wszystko, co może przyczynić się do wyjaśnienia sprawy, a nie jest sprzeczne z prawem. Mając na uwadze ostatnią część tej dyspozycji „a nie jest sprzeczne z prawem”, trzeba stwierdzić, że organ wydający decyzję w sprawie wpisu na listę nie może, uzasadniając swoją decyzję o odmowie wpisu, ze względu na brak nieskazitelnego charakteru z powodu dopuszczenia się w przeszłości przestępstwa, jako podstawę stwierdzenia tego faktu przywołać na przykład informację z KRK, z której wyni$\mathrm{ka}$, że skazanie uległo zatarciu, a wpis o nim (deklaratoryjny) nie został jeszcze usunięty, czy jeżeli z tej informacji wynika, że w chwili wydania decyzji skazanie to już ulegnie zatarciu. Zasadniczo można stwierdzić, że wykazywanie jakimkolwiek środkiem dowodowym, rzeczowym lub osobowym, faktu skazania, które uległo zatarciu, trzeba uznać za kontrskuteczne, gdyż zatarcie skazania jest fikcją prawną, a nie domniemaniem, oznacza to, że nie można stosować w tym wypadku przeciwdowodu do jej obalenia. Artykuł $107 \S 3$ k.p.a. w zw. z 11 pkt 6 przewiduje wymóg uzasadnienia decyzji (w tym wypadku w formie uchwały) pod względem faktycznym i prawnym. Uzasadnienie faktyczne powinno w szczególności zawierać wskazanie faktów, które organ uznał za udowodnione, i dowodów, na których się oparł. W wyroku z dnia 22 października 1981 roku NSA w Warszawie ${ }^{17}$, uzasadniając uchylenie zaskarżonej decyzji, wskazuje, iż

15 Wyrok WSA w Warszawie z 24 maja 2016 roku, VI SA/Wa 2791/15, LEX nr 2090222.

16 Wyrok NSA w Warszawie z 5 kwietnia 2001 roku, II SA 725/00, LEX nr 53476.

17 I SA 2067/81, ONSA 1981/2/103. 
w związku z tym, że we wszystkich tych wypadkach chodzi o orzeczenia, co do których z mocy prawa nastąpiło zatarcie skazania bądź ukarania. W świetle art. 110 k.k. i odpowiednio art. $46 \S 1$ k.w. powoływanie się na kary objęte zatarciem jest niedopuszczalne i nieskuteczne, gdyż samo prawo uważa te kary za niebyłe. Działanie przeciwne, mające miejsce w omawianej sprawie, jest więc obrazą wymienionych przepisów prawa, a ponadto jest naruszeniem art. 75 k.p.a., zgodnie z którym nie może być dopuszczony dowód sprzeczny z prawem (a contrario z treści art. 75 k.p.a.) [...]. Trzeba bowiem mieć na względzie, że fakty takie musiałyby być udowodnione w postępowaniu administracyjnym w inny sposób niż przez powołanie się na wyrok (orzeczenie).

Pogląd ten, choć wyrażony w 1981 roku, zasługuje na aprobatę z uwagi na jednoznaczne związanie organu administracji publicznej postanowieniem art. $106 \mathrm{k} . \mathrm{k}$. To rozumowanie jest dalej podzielane w orzecznictwie, z zastrzeżeniem, że nie można powoływać się na fakt skazania, jeżeli skazanie to zostało zatarte, co nie wyklucza możliwości wykazania zachowania będącego podstawą skazania w drodze innych źródeł dowodowych, na przykład zeznań świadków ${ }^{18}$.

18 Uchwała SN z 27 listopada 1984 roku, III AZP 6/84, OSNC 1985/8/105 — „Okoliczność, że skazanie za określone przestępstwo uległo zatarciu (art. 110 i nast. k.k.), nie wyłącza możliwości oceny zachowania się osoby, w stosunku do której zatarcie nastąpiło, celem ustalenia, czy spełnia ona warunki z ustawy z dnia 26 maja 1982 r. o szczególnych uprawnieniach kombatantów (Dz.U. $\mathrm{Nr} 16$, poz. 122) do uzyskania świadczeń w tej ustawie przewidzianych"; wyrok NSA w Warszawie z 12 maja 1999 roku, III SA 7339/98, LEX nr 45099 — „Zatarcie skazania nie stanowi przeszkody do ustalenia w trybie art. 75 k.p.a., że wnioskodawca w sprawie o wydanie pozwolenia na broń popełnił czyn, który sam w sobie lub w powiązaniu z innymi okolicznościami rodzi obawę, że osoba ta użyje broni w celach sprzecznych $\mathrm{z}$ interesem porządku publicznego [...]. Zatarcie skazania pozwala wprawdzie daną osobę uważać za niekaraną, jednakże przy ocenie osobowości kandydata do posiadania broni ważny jest nie tyle fakt ukarania bądź nieukarania, ale dotychczasowe życie i sposób postępowania tej osoby [...]. Nie można jedynie powoływać się na fakt skazania. Skoro nie ma przeszkód, aby świadkowie zeznawali w postępowaniu administracyjnym, np. o tym, że dana osoba od lat nadużywa alkoholu (co oczywiście nie dotyczy wnioskodawcy w sprawie rozpatrywanej), to tym bardziej nie sposób zabronić organom administracyjnym przeprowadzania dowodów, co do zdarzeń, które w innym postępowaniu zostały zakwalifikowane jako przestępstwa, mimo że później skazanie zostało zatarte. Zdarzenia te mogą być ustalone w trybie art. 75 k.p.a.”; wyrok WSA w Warszawie z 17 lipca 2008 roku, VI SA/Wa 669/08, LEX nr 491336 — „W tej sytuacji powołanie się przez organ drugiej instancji na wyrok sądowy, co do którego nastąpiło zatarcie skazania z mocy prawa, jest naruszeniem art. 75 k.p.a., zgodnie z którym nie może być dopuszczony dowód sprzeczny z prawem (a contrario z treści art. 75 k.p.a.). W świetle art. 106 k.k. i odpowiednio art. 37 k.k.w. powoływanie się na kary objęte zatarciem jest niedopuszczalne i nieskuteczne, gdyż samo prawo uważa te kary za niebyłe. Jednakże, zarówno orzecznictwo Naczelnego Sądu Administracyjnego, jak i Sądu Najwyższego oraz doktryna przyjmują, iż zatarcie skazania nie stanowi przeszkody do dokonywania ustaleń w trybie art. 75 k.p.a. [...]. Zatarcie skazania pozwala wprawdzie daną osobę uznać za niekaraną, jednakże przy ocenie rękojmi ważny jest nie tyle fakt ukarania bądź nieukarania, ale dotychczasowe życie i sposób postępowania tej osoby. Można zatem w postępowaniu administracyjnym ustalić, że doszło do działania na szkodę jakiejś osoby (fizycznej lub prawnej), skutkiem czego uszczuplony został jej majątek. Nie można jedynie powołać się na fakt skazania, co wadliwie uczynił organ drugiej instancji. Zgodnie z dyspozycją art. $75 \S 1$ k.p.a., organ administracyjny może w granicach prawa przeprowadzić wszelkie

Studenckie Prace Prawnicze, Administratywistyczne

i Ekonomiczne 30, 2019

(C) for this edition by CNS 
Pojawiające się najczęściej nieporozumienia dotyczące omawianej kwestii powodowane są niezauważaniem różnicy między powoływaniem się na fakt skazania, które z chwilą zatarcia uważa się za niebyłe, a wykazywaniem niespełniania przesłanek nieskazitelnego charakteru i dawania rękojmi prawidłowego wykonywania zawodu. Organ administracji publicznej nie może powoływać się na fakt skazania, gdyż działałby wbrew jednoznacznej dyspozycji art. 106 k.k., jednak nie oznacza to, że zachowanie, które wypełnia znamiona czynu zabronionego, który z samej swej istoty musi być naganny i społecznie szkodliwy, będący podstawą orzeczenia, nie może zostać wykazane innymi środkami dowodowymi. Fikcja prawna dotycząca skazania nie zmienia rzeczywistości pozanormatywnej, jednakże ogranicza organ co do możliwości wykazywania pewnych faktów o charakterze prawnym.

\section{Podsumowanie}

W postępowaniu dotyczącym wpisu na listę adwokatów lub radców prawnych odpowiednio okręgowa rada adwokacka i rada okręgowej izby radców prawnych działają jako organy administracji w rozumieniu art. $5 \S 2$ pkt 3 k.p.a. Implikuje to związanie ich postanowieniami tego kodeksu odnoszącymi się do postępowania administracyjnego, a w szczególności postępowania dowodowego. Również podmioty te przy wydawaniu uchwał $\mathrm{w}$ omawianym przedmiocie są związane zasadami konstytucyjnymi i są zobowiązane do działania jedynie na podstawie i w granicach prawa. Wymóg nieskazitelnego charakteru i dawania swoim dotychczasowym zachowaniem rękojmi prawidłowego wykonywania zawodu stawiany kandydatowi do wpisu na listę adwokatów czy radców prawnych jest ze swej istoty ocenny $^{19}$, co nie jest wadą tego rozwiązania, chociaż pociąga za sobą problemy dotyczące stwierdzenia spełniania tych warunków. Do ich stwierdzenia powołane są okręgowa rada adwokacka i rada okręgowej izby radców prawnych. Na nich ciąży obowiązek działania z urzędu lub na wniosek celem dokładnego wyjaśnienia stanu faktycznego i na podstawie zebranego całego materiału dowodowego oraz jego wszechstronnego rozważenia (art. 7, art. $77 \S 1$ i art. 80 k.p.a.) orzeczenie ${ }^{20}$, czy kandydat wnioskujący o wpis na odpowiednią listę spełnia wymagania przepisane prawem, czy też nie. Można wskazać, że ani samoistny fakt skazania, ani fakt bycia niekaranym ${ }^{21}$, ani żaden z pojedynczych wycinków z życia prywatne-

dowody (np. z przesłuchania świadków) co do zdarzeń, które w innym postępowaniu zostały zakwalifikowane jako przestępstwa, mimo że później skazanie zostało zatarte".

19 Zob. wyrok WSA w Warszawie z 26 listopada 2013 roku, VI SA/Wa 1379/13, LEX nr 1415145.

20 Wyrok NSA z 23 lutego 1999 roku, II SA 1888/98, LEX nr 46707; wyrok WSA w Warszawie z 3 marca 2010 roku, VI SA/Wa 2109/09, LEX nr 607004.

21 Wyrok NSA w Warszawie z 2 września 2015 roku, II GSK 1840/14, LEX nr 1816437; wyrok NSA w Warszawie z 11 marca 2014 roku, II GSK 2052/12, LEX nr 1490511. 
$\mathrm{go}^{22}$ lub zawodowego ${ }^{23}$ kandydata nie może być niezależną od innych podstawą stwierdzenia spełniania bądź niespełniania tych przesłanek. Jedynie całokształt dotychczasowego życia kandydata może wskazać, czy jest on nieskazitelnego charakteru ${ }^{24} \mathrm{i}$ czy daje rękojmię prawidłowego wykonywania zawodu adwokata albo radcy prawnego.

\section{Bibliografia}

\section{Literatura}

Bogdan G., [w:] Kodeks karny. Część ogólna, t. 1, cz. 2. Komentarz do art. 53-116, red. W. Wróbel, A. Zoll, Warszawa 2016.

Duniewska Z., Podstawowe pojęcia prawa administracyjnego, [w:] Prawo administracyjne. Pojęcia, instytucje, zasady w teorii i orzecznictwie, red. M. Stahl, Warszawa 2016.

Dziedziak W., O dyskrecjonalności administracji publicznej w procesach stosowania prawa, „Studia Iuridica Lublinensia" 2017, nr 3.

Jaśkowska M., Uznanie administracyjne a inne formy władzy dyskrecjonalnej administracji publicznej, [w:] System Prawa Administracyjnego, t. 1. Instytucje prawa administracyjnego, red. R. Hauser, Z. Niewiadomski, A. Wróbel, Warszawa 2015.

Kłączyńska N., [w:] Kodeks karny. Część ogólna. Komentarz, red. J. Giezek, wyd. 2, Warszawa 2012.

Marek A., Kodeks karny. Komentarz, wyd. 5, Warszawa 2010.

Przybysz P.M., Kodeks postępowania administracyjnego. Komentarz, wyd. 12, Warszawa 2017.

Wróbel A., [w:] Kodeks postępowania administracyjnego. Komentarz, red. A. Wróbel M. Jaśkowska, M. Wildbrandt-Gotowicz, wyd. 7, Warszawa 2018.

Zgoliński I., [w:] Kodeks karny Komentarz, red. V. Konarska-Wrzosek, wyd. 2, Warszawa 2016.

\section{Orzecznictwo}

Orzeczenie TK z 29 września 1993 roku, K 17/92, OTK 1993, nr 2, poz. 33.

Uchwała SN z 27 listopada 1984 roku, III AZP 6/84, OSNC 1985, nr 8, poz. 105.

Uchwała SN z 5 lutego 1988 roku, III AZP 1/88, LEX nr 11678.

Wyrok SN z 20 września 2007 roku, SNO 60/07, LEX nr 471853.

Wyrok SN z 18 czerwca 2009 roku, IV KK 164/09, LEX nr 512114.

Wyrok SN z 29 sierpnia 2013 roku, IV KK 168/13, LEX nr 1403563.

Wyrok NSA w Warszawie z 11 czerwca 1981 roku, SA 820/81, LEX nr 9626.

Wyrok NSA w Warszawie z 12 maja 1999 roku, III SA 7339/98, LEX nr 45099.

Wyrok NSA w Warszawie z 18 czerwca 2001 roku, II SA 1610/00, LEX nr 53475.

Wyrok NSA w Warszawie z 18 listopada 1999 roku, II SA 1131/99, LEX nr 46696.

Wyrok NSA w Warszawie z 22 października 1981 roku, I SA 2067/81, ONSA 1981, nr 2, poz. 103. Wyrok NSA w Warszawie z 5 kwietnia 2001 roku, II SA 725/00, LEX nr 53476.

22 Wyrok NSA w Warszawie z 8 stycznia 2015 roku, II GSK 2074/13, LEX nr 1658783.

23 Wyrok NSA w Warszawie z 29 sierpnia 2017 roku, II GSK 3350/15, LEX nr 2399469.

24 „Pojęcie »nieskazitelności« zastosowane w art. 65 pkt 1 ustawy z dnia 26 maja 1982 r. nie może być pojmowane jako brak jakiejkolwiek skazy czy też brak negatywnych okoliczności w dotychczasowej postawie kandydata do zawodu adwokata. Takie podejście uznać trzeba za zbyt restrykcyjne" - wyrok NSA w Warszawie z 5 lutego 2008 roku, II GSK 325/07, LEX nr 489599. 
Wyrok NSA z 23 lutego 1999 roku, II SA 1888/98, LEX nr 46707.

Wyrok NSA z 21 lutego 2007 roku, II GSK 302/06, LEX nr 927339.

Wyrok NSA z 5 lutego 2008 roku, II GSK 325/07, LEX nr 489599.

Wyrok NSA z 10 lutego 2009 roku, II GSK 744/08, LEX 522554.

Wyrok NSA z 7 marca 2013 roku II GSK 1825/12, LEX nr 1305501.

Wyrok NSA z 29 stycznia 2014 roku, II GSK 1958/12, LEX nr 1450736.

Wyrok NSA z 11 marca 2014 roku, II GSK 2052/12, LEX nr 1490511.

Wyrok NSA z 8 stycznia 2015 roku, II GSK 2074/13, LEX nr 1658783.

Wyrok NSA z 16 stycznia 2015 roku, I OSK 1678/13, LEX nr 1624283.

Wyrok NSA z 2 września 2015 roku, II GSK 1840/14, LEX nr 1816437.

Wyrok NSA z 14 kwietnia 2016 roku, II GSK 2647/14, LEX nr 2139464.

Wyrok NSA z 2 sierpnia 2016 roku, II GSK 259/15, LEX nr 2142251.

Wyrok NSA z 1 grudnia 2016 roku, II GSK 1117/15, LEX nr 2295021.

Wyrok NSA z 29 sierpnia 2017 roku, II GSK 3350/15, LEX nr 2399469.

Wyrok NSA z 17 listopada 2017 roku, II GSK 447/16, LEX nr 2430732.

Wyrok TK z 31 marca 2005 roku, OTK-A 2005/3/29.

Wyrok TK z 7 maja 2002 roku, SK 20/00, OTK-A 2002/3/29.

Wyrok WSA w Warszawie z 29 marca 2007 roku, VI SA/Wa 172/07, LEX nr 334877.

Wyrok WSA w Warszawie z 17 lipca 2008 roku, VI SA/Wa 669/08, LEX nr 491336.

Wyrok WSA w Warszawie z 4 listopada 2009 roku, VI SA/Wa 1450/09, LEX nr 589497.

Wyrok WSA w Warszawie z 3 marca 2010 roku, VI SA/Wa 2109/09, LEX nr 607004.

Wyrok WSA w Warszawie z 21 lipca 2010 roku, II SA/Wa 633/10, LEX nr 667345.

Wyrok WSA w Warszawie z 26 listopada 2013 roku, VI SA/Wa 1379/13, LEX nr 1415145.

Wyrok WSA w Warszawie z 10 kwietnia 2014 roku, VI SA/Wa 2883/13, LEX nr 1504776.

Wyrok WSA w Warszawie z 24 maja 2016 roku, VI SA/Wa 2791/15, LEX nr 2090222.

Wyrok WSA w Warszawie z 9 marca 2017 roku, VI SA/Wa 1863/16, LEX nr 2284691.

Wyrok WSA w Warszawie z 5 kwietnia 2017 roku, VI SA/Wa 2133/16, LEX nr 2441474.

Wyrok WSA w Warszawie z 20 kwietnia 2017 roku, VI SA/Wa 2223/16, LEX nr 2315928

\section{Akty prawne}

Konstytucja Rzeczypospolitej Polskiej z dnia 2 kwietnia 1997 roku (Dz.U. z 1997 r. Nr 78, poz. 483).

Ustawa z dnia 14 czerwca 1960 roku Kodeks postępowania administracyjnego (tekst jedn. Dz.U. z 2018 r. poz. 2096 ze zm.).

Ustawa z dnia 26 maja 1982 roku Prawo o adwokaturze (tekst jedn. Dz.U. z 2018 r. poz. 1184 ze zm.).

Ustawa z dnia 6 lipca 1982 roku o radcach prawnych (tekst jedn. Dz.U. z 2018 r. poz. 2115 ze zm.).

Ustawa z dnia 6 czerwca 1997 roku Kodeks karny (tekst jedn. Dz.U. z 2018 r. poz. 1600 ze zm.).

Ustawa z dnia 6 czerwca 1997 roku Kodeks postępowania karnego (tekst jedn. Dz.U. z 2018 r. poz. 1987 ze zm.).

Ustawa z dnia 25 lipca 2002 roku Prawo o ustroju sądów administracyjnych (tekst jedn. Dz.U. z 2018 r. poz. 2107 ze zm.). 